\title{
HUMAN DEVELOPMENT INDEX, UNEMPLOYMENT AND POVERTY IN PAPUA PROVINCE, 2010-2015
}

\author{
Nurisqi Amalia ${ }^{1}$, Anisa Nurpita ${ }^{2}$, Rina Oktavia ${ }^{3}$ \\ Department of Applied Economic, Faculty Economic and Business, \\ University of Gadjah Mada \\ Email: ${ }^{1}$ nurisqi.amalia@ugm.ac.id, ${ }^{2}$ anisanurpita@ugm.ac.id, ${ }^{3}$ rina.oktavia@ugm.ac.id
}

\begin{abstract}
Papua Province is one of the poorest provinces in Indonesia. Some of the variables that affect health levels including Human Development Index (HDI) and unemployment rate. This research analyzes Human Development Index and unemployment rate to poverty level in districts/cities in Papua Province during 2010-2015. Research data used in this research is secondary data from Central Bureau of Statistics of district/city in Papua Province. The independent variables used are open unemployment rate and Development Index. While the dependent variable used is poverty level in districts/citis in Papua Province year 2010-2015. The analysis tool used is regression with panel data. The result of this research shows that the average of district/city's poverty rate in Papua 2010-2015 is 32,34 percent. The highest level is in District Deiyai and the lowest is in District Merauke. The Human Development Index has decreased significantly to the poverty rate of district/city in Papua Province, while the open unemployment rate is positive to the poverty rate of district/city in Papua Province. Human Development Index and open unemployment rate as a whole and together affect poverty level in district/city in Papua Province.
\end{abstract}

Keywords: human development index, open unemployment, panel data, poverty, regression.

\section{INTRODUCTION}

Poverty is a problem faced by all countries in the world, not excepting to rich countries like the United States, belonging to the most powerful and superpower countries and countries dominating but in fact, there are still millions of people who are poor. In addition, poverty has a disproportionate distribution pattern between regions within a country and between countries in those areas. Almost half of all poor people live in South Asia with a smaller population, but the level of inequality remains substantial. In almost every country, poverty is always concentrated in certain areas, usually in rural areas or in resource-poor areas. The problem of poverty is also closely related to other problems, such as environmental problem (Kuncoro 1997).

Poverty is a main issue of development in Indonesia both at the central and regional levels, even a global problem. Handling poverty is the responsibility of central and local governments and all stakeholders. Poverty alleviation will be better if the handling is cross-sectoral and coordinated well, so there is synergy in the 
implementation of poverty reduction programs.

Based on data from the Central Bureau of Statistics (BPS) in 2016, the number of poor (people with per capita expenditure per month below the Poverty Line) in Indonesia in September 2016 reached 27.76 million people (10.70 percent of the total population), or decreased by 0.25 million people compared to March 2016 of 28.01 million people (10.86 percent of the total population). During March 2016-September 2016, the percentage of poverty in Indonesia decreased, but if it is seen more in other problems emerged that the increase of poor in urban areas as much as 0.15 million people (from 10.34 million people in March 2016 to 10.49 million people in September 2016), while the number of poor in rural areas decreased by 0.39 million people (from 17.67 million people in March 2016 to 17.28 million people in September 2016).

Based on the BPS poverty profile, although the number of rural poverty decreased, but the percentage of the poor increased. In March 2015 the percentage of the poor in rural areas stood at 14.21 percent, then fell in September 2015 to 14.09 percent then rose 0.02 percent in March 2016 to 14.11 percent. Referring to the Farmer Stock Exchange (NTP) data, it continued to decline from 102.55 in January 2016 to 101.47 in June 2016, it is natural that the percentage of rural poverty increases, as agricultural business declines.

The index of rural poverty depth in March 2015 is 2.55 or lower than March 2016 of 2.74 . This indicates that the average size of the disparity of expenditure of each poor on the poverty line is still high. Along with that, the index of rural poverty severity in the same period also increased from 0.71 to 0.79 . Based on the monthly report of socio-economic data of BPS in July 2016, in the period of February 2015 - February 2016, the agricultural workforce decreased by 1.83 million people from 40.12 million people down to 38.29 million people.

Poverty alleviation and community empowerment are the main goals of central and local governments. Efforts and programs that have been done are to build and apply various anti-poverty programs such as Raskin, BLT, IDT BOS, etc., all of which are aimed at reducing the burden on the poor. The failure of current government programs to reduce poverty does not mean that these programs are not beneficial at all, but at least have helped the poor in meeting their needs, it is necessary to empower poor people fundamentally, so that the poor have robust economic resilience facing the 
environmental turmoil and the economic risks it faces.

Meanwhile, the efforts to eradicate poverty will be meaningless if the programs are planned by the government on the basis of perceived misperceptions and assumptions about the causes of poverty and anti-poverty program planning and implementation, irrespective of the variation in the definition and causes of poverty and the weak government monitoring against the program.

According to data from Papua Province BPS in 2016, the percentage of the poor in Papua over the past six months has increased by 0.14 percentage points from 28.40 percent in September 2015 to 28.54 percent in March 2016. Viewed by type of region, the poor is concentrated in rural areas, in March 2016 as many as 37.14 percent of the poor lived in rural areas while in urban areas only 4.42 percent. The poverty line (GK) in urban areas in March 2016 amounted to Rp446,985, - higher than the rural GK which reached Rp412,991. This means, the cost to meet the minimum basic needs for food and non-food is greater in urban than in rural areas. The role of food commodity to GK is much greater than the role of non-food commodities (housing, clothing, education, and health), which is 75.36 percent versus 24.64 percent. Food commodities that have a large effect on GK in urban areas are rice, clove cigarette filter and tuna. While commodities that have a big effect on GK in rural areas are sweet potatoes, rice, and clove cigarettes filter. In September 2015 - March 2016, Poverty Depth Index (P1) and Poverty Severity Index (P2) showed a very significant upward trend. This indicates that the average spending of the poor tends to move further away from the poverty line and the disparities in the expenditure of the poor are widening.

Viewed by type of region, the poor in Papua are concentrated in rural areas, where in March 2016 there were 37.14 percent of the poor living in rural areas, while in urban areas only 4.42 percent. When compared to the previous period (September 2015), there was an increase in the percentage of poor people in urban areas by 0.81 percentage points (22.33 percent). But the opposite happened in rural areas, the number of poor people decreased by 0.2 percentage points ( 0.53 percent).

Central Bureau of Statistics (BPS) recorded the number of poor people as per September 2016 as many as 27.76 million people. This figure is reduced 250 thousand people from the number of poor people in March 2016 which as many as 28.01 million people. Of the 34 provinces in Indonesia, 
the poorest provinces are in Papua. From BPS data, Papua Province has the highest percentage of poor people in September 2016, which is 28.4 percent. The number of poor people in Papua in September 2016 was 914,87 thousand.

Until now, human development in Papua Province is still "low" indicated by the number of Human Development Index (HDI) which is still below 60. Nevertheless, human development in Papua continues to make progress as reflected by the continuous rise of HDI. Papua HDI by 2015 is 57.25. This figure is 0.50 points higher than in 2014 which was recorded at 56.75. In other words, Papua HDI by 2015 increases. During the period 2014 to 2015, the forming components of HDI also increased by 0.88 percent compared to the previous year. The increase in newborns has a life probability of 65.09 years, which is an increase of 0.25 years compared to the previous year. 7-year-olds have an opportunity to attend school for 9.95 years, increased by 0.01 years from the previous year. The population aged 25 years and over on average have been educated for 5.99 years, increased by 0.23 years compared to the previous year. Per capita expenditure adjusted (constant 2012 prices) of the community of Rp6.47 million per year, increased Rp52.44 thousand compared to the previous year.

HDI is formed by three basic dimensions, namely long and healthy life; knowledge; and decent standard of living. Longevity and healthy living are depicted with Life Expectancy at birth (AHH), which is the number of years expected by newborns to live, assuming that the pattern of death rates by age at birth is the same throughout the age of the infant. The dimensions of knowledge are measured through the indicators of the Old School and Old School Expectations. Average School Length (RLS) is the average length (years) of population aged 25 years and over in formal education. School Old Expectancy (HLS) is defined as the duration (year) of the formal school that is expected to be felt by the child at a certain age in the future. Meanwhile, the standard of living deserves to be described by per capita expenditure, which is determined from the value of per capita expenditure and purchasing power parity.

The number of labor force in Papua in February 2016 reached 1,743,160 people, an increase of 1,215 people compared to August 2015. The population of working people in Papua in February 2016 reached $1,691,432$ people, an increase of 18,952 people compared to August 2015 and 
increased by 45,375 people compared to the previous year (February 2015). The number of unemployed in February 2016 was 51,728 people, decreased by 17,737 people compared to August 2015 and also decreased by 11,883 people compared to February 2015. Over the past year, the Open Unemployment Rate (TPT) in Papua has decreased from 3.72 percent in February 2015 to 2.97 percent in February 2016. Similarly, when compared with August 2015 declined from 3.99 percent to 2.97 percent.

Poverty can be generated by biased policies. The number of poor people in rural areas is still quite a lot compared to urban areas. In 2012, the percentage of poor people living in rural areas is 9.08 percent or 282 thousand, while poor people live in urban areas of 5.74 percent or 77 thousand poor people. During 2007-2012, poverty in urban areas decreases faster than in rural areas. The high level of poverty in rural areas is due to the policy of the biased urban development and industrial sector, while the allocation of agriculture budget decreases drastically (Sajogyo 2002 in Murohman 2014). This policy is considered to be misleading because it marginalizes people's rights and fosters the pockets of urban community prosperity among rural poverty (Sudaryanto and Rusastra 2006 in Murohman 2014).

According to Nasoetion 1993 in Ravallion and Datt 2002, poverty in the economic viewpoint is a reflection of low aggregate demand. Low aggregate demand will reduce intensive to develop production and income of labor as a factor of production. Poverty reduction occurs when there is economic growth. However, the magnitude of poverty reduction is determined by the composition of the growth of the economic sector where the largest poor are. According to Putri (2013), factors that affect the level of poverty are HDI, PDRB, and public spending. According to Harlik, Amir and Hardiani (2013), factors affecting poverty are population density, education level and unemployment rate. So, the title of this study is the effect of HDI and Unemployment Rate on Poverty level in Papua Province 2010-2015

The formulations of this research problem is the decrease of unemployment rate, the low level of HDI in Papua Province and the high level of poverty in the province, Hence, it needs a research about the influence of HDI and unemployment level to poverty level in Papua Province. This study aims to determine the comparison of Poverty Rate, to estimate the 
partial effects of HDI and unemployment rate on poverty level, and to estimate the simultaneous effect of HDI and unemployment rate on poverty level in the districts/ cities in Papua Province during 2010-2015.

\section{METHODS}

This study uses secondary data obtained from BPS of Papua Province. The data used is time series data from 20102015 and cross section data with thirty (29) districts / cities in Papua Province. This research model refers to research conducted by Putri (2010). The research model used in this research is:

$$
\mathrm{K}=\boldsymbol{\alpha}+\boldsymbol{\beta 1} \mathrm{IPM}+\boldsymbol{\beta 2} \mathrm{TP}+\mathrm{e}
$$

Description:

$$
\begin{array}{ll}
\text { K } & \text { : Poverty level } \\
\alpha & \text { : Constant } \\
\text { IPM } & \text { : Human Development Index } \\
\text { TP } & \text { : Unemployment rates } \\
\text { e } & \text { : error term }
\end{array}
$$

The analysis is done by using regression with panel data. Panel data (pooled data) is a data set containing individual sample data (household, company, district / city, etc.) at a certain time period. Panel data is a combination of cross-time and cross-section data. Panel data is very useful data because this type of data helps researchers to explore the economic actor activities not only between individuals but cross-time economic behavior (Ekananda, 2016).

The panel data regression analysis tool has a panel data approach that can be selected to estimate panel data in the study. According to Pambudi. AE, and Judge. L. (2013) panel data approach include:

\section{Pooled Least Square/Common Effect}

Pooled Least Square is a simple approach to estimating panel data. This approach combines only time series and cross section data using the OLS method known as the Common Effect estimation

\section{Fixed Effect Method}

Problems encountered in Pooled Least Square analysis are the assumption of intercept and slope of the regression equation that is considered constant both between regions and between time.

\section{Random Effect Method}

A panel data analysis approach with fixed effect through dummy variable technique or LSDV still leaves a little problem that is the uncertainty of the model that we use.

The statistical test diagram to select the model used can be shown in the following steps:

1. Chow Test $\mathrm{F}$ statistics test is a test to choose whether the model used Pooled 
Least Square or Fixed Effect. As we know, sometimes the assumption that each unit of cross section has the same behavior which is unrealistic in view of the possibility that each cross-section unit has a different behavior. The test is performed with the following hypotheses:

H0: PLS Model (Restricted)

H1: Fixed Effect Model (Unrestricted)

2. Hausman Test is a statistical test as the basis of our consideration in choosing whether to use a fixed effect model or a random effect model. As we know that the use of fixed effect model contains a trade off element that is loss of degrees of freedom by entering dummy variables. However, the use of the random effect method should also take into account the absence of violation of the assumption of any error component. This test is performed with the following hypotheses:
H0: Random Effects Model

H1: Fixed Effects Model

3. LM Test or The Breusch - Pagan LM Test is used as a statistical consideration in choosing Random Effect or Pooled Least Square model.

H0: PLS Model

H1: Random Effect Model

As the basis of the rejection of $\mathrm{H} 0$ by using LM statistics following the distribution of Chi Squre.

\section{RESULTS AND DISCUSSION}

\section{Best Model Selection}

The data estimation is done by several tests. The test is performed to determine the best model to be used in linear regression analysis. The estimation result from common effects model, fixed effect and random effect model is shown in Table 1.

Table 1. The Result of Estimation Model

\begin{tabular}{lccc}
\hline & \multicolumn{2}{c}{ Dependent Variable: Poverty Level } & \\
\cline { 2 - 3 } \multicolumn{1}{c}{ Variable } & Independent Variable: IPM, Unemployment & \\
Common Effect & Fixed Effect & Random Effect \\
C & 62,25086 & 106,2680 & 84,24976 \\
IPM & $(0,0000)^{*}$ & $(0,0000)^{*}$ & $(0,0000)^{*}$ \\
& $-0,559517$ & $-1,386243$ & $-0,970687$ \\
Unemployment & $(0,0000)^{*}$ & $(0,0000)^{*}$ & $(0,0000)^{*}$ \\
R-Squared & 0,098938 & 0,201549 & 0,176804 \\
Adjusted R-Squared & $(0,6155)^{*}$ & $(0,0130)^{*}$ & $(0,0273)^{*}$ \\
F Statistic & 0,528466 & 0,972836 & 0,489970 \\
Prob (F-Statistic) & 0,522951 & 0,967138 & 0,484004 \\
Observation & 95,82319 & 170,7136 & 82,13709 \\
\cline { 1 - 2 } Source: Processed Data & 0,0000000 & 0,000000 & 0,000000 \\
\hline
\end{tabular}


Based on Table 1, the estimation will be tested to determine the best model to be used in this research. Testing for model estimation includes: $\mathrm{F}$ test (Chow Test), Hausmant Test, and Langrage Multiplier Test (LM Test).

\section{Table 2. Estimation Model Test}

\begin{tabular}{ccc}
\hline V & $\begin{array}{c}\text { Prob. F- } \\
\text { Test } \\
\text { (PLS vs } \\
\text { FE) }\end{array}$ & $\begin{array}{c}\text { Prob. } \\
\text { Hausmant- } \\
\text { Test } \\
\text { (FE vs RE) }\end{array}$ \\
\hline $\begin{array}{c}\text { Cross-section } \\
\text { F }\end{array}$ & 0,0000 & - \\
$\begin{array}{c}\text { Cross-section } \\
\text { Chi-square } \\
\text { Cross-section } \\
\text { Random }\end{array}$ & 0,0000 & - \\
Conclusion & - & 0,0000 \\
Source: Processed Data & FE & FE \\
\hline
\end{tabular}

From Table 2, the model test results can be seen in the probability value of $F$ test (Chow Test) with a value of 0.0000 . It can be concluded that the null hypothesis is rejected because the probability value of cross-section $\mathrm{F}$ is less than alpha (5\%). Thus, based on chow test, the model chosen is fixed effect. From the Hausmant test, based on the result of output eviews 9, we can get the result of the random crosssection probability of 0.0000 . Thus, it can be concluded that the fixed effect model is the best model in estimation using Hausmant Test.

Of the two calculations are not found in the form of a common effect model, so there is no need to test LM. From the $\mathrm{F}$ test and Hausman test that has been done, the best model to use is fixed effect because the relationship between fixed effect model variable has been in accordance with existing theory, while for the common effect and random effect, the relationship between the variables is not in accordance with the existing theory. Thus, it can be concluded that the best model to be used according to the two tests that have been done is fixed effect.

\section{The Effect of HDI and Unemployment}

\section{Rate on Poverty Level in districts / cities}

\section{in Papua Province 2010-2015}

Partial testing basically indicates how far each independent variable influences individually in explaining the variation of the dependent variable. In this case, the independent variables are Human Development Index (HDI) and Unemployment Rate, while the dependent variable is poverty level. Partial test is seen from the value of probability. The variable is said to be significant if the probability value is less than the significance value $(5 \%)$.

\section{Table 3. T-Statistic Value}

Dependent Variable: Poverty Level

\begin{tabular}{cccc}
\hline Variable & \multicolumn{2}{c}{ Equation } & \\
& $\begin{array}{c}\text { t- } \\
\text { Statistic }\end{array}$ & Prob. & \\
\hline IPM & - & 0,0000 & Signifikan \\
Unemployment & 2.515130 & 0,0130 & Signifikan \\
\hline Source: Processed Data & &
\end{tabular}


Based on Table 3, the Human Development Index (IPM) has a significant effect on poverty rate. Similarly, unemployment rate has a significant effect on poverty level.

Based on chow test, hausman test, and lagrange multiplier test, the best model used is fixed effect model. The equation obtained is:

$$
\begin{aligned}
& \mathrm{K}_{\mathrm{it}}=106,2680-1,386243 \text { IPM }_{\text {it }}+ \\
& 0,201549 \mathrm{TP}_{\mathrm{it}}+\mathrm{e}_{\mathrm{it}}
\end{aligned}
$$

Description:

$$
\begin{array}{ll}
\text { K } & \text { : Poverty level } \\
\alpha & : \text { Constant } \\
\text { IPM } & : \text { Human Development Index } \\
\text { TP } & : \text { Unemployment rates } \\
\text { i } & : \text { Districts/cities } \\
\text { t } & : \text { Periods } \\
\text { e } & \text { : error term }
\end{array}
$$

Then it is obtained the results of the analysis as follows:

\section{Poverty Level (K)}

The poverty level of the districts/cities is constant and significant. This means that there are other important variables that have not been included in the model, for example: inflation, population, PDRB and others.

\section{Human Development Index (IPM)}

Human Development Index (HDI) has a negative and significant effect on poverty rate. This means that higher
Human Development Index will reduce the poverty rate. If the Human Development Index increases 1 percent, it will reduce the poverty rate by 1.39 percent.

\section{Unemployment rate (TP)}

Unemployment rate (TP) has a positive and significant influence on poverty rate. This means that higher unemployment rate will increase the poverty rate. If the unemployment rate increases by 1 percent, it will reduce the poverty rate by 0.20 percent.

Testing of simultaneous effect of all independent variables in the model can be done by Simultaneous Test (Test F). The simultaneous test basically shows whether all the independent variables included in the model have a mutual influence on the dependent variable.

Table 4. F-Statistic

\section{Equation}

\begin{tabular}{cc}
\hline F-Statistic & Prob. \\
\hline 170,7136 & 0,000000 \\
\hline
\end{tabular}

Source: Processed Data

From Table 4, we use the 95\% confidence level $(\alpha=5 \%)$, with $\mathrm{df}=\mathrm{nk}=$ $174-2=172$, the F-table is 3.05 and the FStatistic value of the equation is 170.7136 and the probability value. The F-Statistic for the equation is 0.0000 . Thus, it can be concluded that $\mathrm{F}$ calculate is greater than $\mathrm{F}$ 
table then Human Development Index (IPM) and unemployment rate as a whole and together affect poverty level in Papua Province.

\section{CONCLUSION AND SUGGESTION}

The Human Development Index (HDI) has a negative and significant effect on the poverty level in the districts / cities in Papua Province. The higher the Human Development Index, the lower the level of poverty. If the Human Development Index increases 1 percent it will reduce the poverty level by 1.39 percent. Unemployment rate (TP) has a positive and significant impact on the level of poverty. The higher the unemployment rate, the higher the poverty level. If the unemployment rate increases by 1 percent it will reduce the poverty level by 0.20 percent. The Human Development Index (IPM) and unemployment rate together affect the poverty level in the districts / cities in Papua Province.

The suggestion that can be given to the government in the Papua Province is to continuously improve the Human Development Index and reduce poverty. The improvement of Human Development Index is done with the improvement of superior programs related to education and health. The decline in poverty can be done by leading poverty reduction programs such as providing business capital for the community and providing training to improve the skills of the community in order to create a marketable product on the market (fostering entrepreneurial spirit).

\section{REFERENCES}

Arsyad, Lincoln. 2010. Ekonomi Pembangunan. Yogyakarta: Unit Penerbit dan Percetakan STIM YKPN.

Duwila, Ummi. 2016. Pengaruh Pendidikan, Pengangguran dan Inflasi terhadap Tingkat kemiskinan di Kawasan Timur Indonesia (KTI). Cita Ekonomika, Jurnal Ekonomi, Vol. X, No. 1, Mei 2016, ISSN: 19783612.

Ekananda, Mahyus. 2014. Analisis Ekonometrika Data Panel. Edisi Pertama. Jakarta: Mitra Wacana Media.

Ekananda, Mahyus. 2015. Analisis Ekonometrika Data Panel. Edisi Kedua. Jakarta: Mitra Wacana Media.

Gujarati, Damodar N. 2006. Basic Econometrics 4th edition.Singapore: Mc Graw Hill.

Harlik, Amir, dan Hardiani. 2013. Faktorfaktor yang mempengaruhi kemiskinan dan pengangguran di Kota Jambi. Jurnal Perspektif Pembiayaan dan Pembangunan Daerah Vol. 1 No. 2, Oktober 2013.

Kuncoro, Mudrajat. 1997. Ekonomi Pembangunan Teori, Masalah, dan Kebijakan. Yogyakarta: Unit Penerbit dan Percetakan Akademi Manajemen Perusahaan YKPN.

Lincolin Arsyad. 1997. Ekonomi Pembangunan. Edisi Ketiga. Penerbit BP STIE YKPN, Yogyakarta. 
Putri, Agustina Mega P. 2013. Faktorfaktor yang mempengaruhi Tingkat kemiskinan di Provinsi Jawa Timur Tahun 2008-2012.

Saputro, Agung Eddy Suryo. 2007. Faktorfaktor yang mempengaruhi Kemiskinan secara Makro di Lima Belas Provinsi tahun 2007. Jurnal Organisasi dan Manajemen, Vol. 6 No. 2, September 2010, 89-100.

Sumanto. 2014. Statistika Terapan.

Cetakan Pertama. Yogyakarta: CAPS.
Todaro, Michael P., and Stephen C. Smith. 2004. Pembangunan Ekonomi di Dunia Ketiga. Jakarta: Penerbit Erlangga.

\section{Laporan Tahunan}

BPS Indonesia Laporan kemiskinan 19982016

Provinsi Papua Dalam Angka BPS Provinsi

Papua 2010-2016 